\title{
PrzePoWIAdANIE SŁOWA Bożego
}

Warszawskie Studia Pastoralne UKSW

Rok XI 2016 Nr 4(33)

Ks. Jan Kazimierz Przyby Łowski

\section{„PROFESSIONALISATION” OF THE PRIESTS’ PRIESTLY WORK}

The church is presented as the whole, constructed from authoritatively set number of elements (dioceses, parishes) in its traditional model. Particular elements are organized in such way that they could reflect the features of the whole. Dioceses, also analogical parishes create the body of the Church, that is the only one, saint, common and missionary. Catholic Church that is made of God's-human structure is of unchangeable hierarchy from its beginning. Diocesan Church is created around the bishop's person and his mission. Due to the above the relations between dioceses have an impact on the salutary missions' realization of the entire church. The aim of the Church's organization ought to be an effective improvement of particular dioceses' activities, owing which the whole body of the church's would be also improved.

The Church's body is very simple: The Church has an only aim - redemption and the only power center - hierarchy. The Church's structure is organized in such a way, that every its element (dioceses, parishes) fulfills the same salutary functions (prophetic, priestly and royal). All dioceses act according to the same norms described in the Magisterium of the Church, for which the Revelation is a source (Bible and Tradition) and precised by the Canonic Law. The hierarchy sees to the fulfilment of salutary functions, that is precisely described rights and duties, this is why their behaviors can be foreseen and at the same time it is a guarantee, that the basic salutary functions are going to be fulfilled.

Fruitfulness of priesthood in the Church depends on the Holy Ghost, but the order of grace assumes the contributions of human's 
effort and work of priests and also secular faithful. However the outer circles (socio-economical, political or cultural) may only indirectly influence on religious life of Christians. Finally it is the God's Providence that decides about the Church's future, and all scientific prognosis is only of helpful nature ${ }^{1}$. Also the importance of ways and even checked priestly methods ought not to be overestimated, since according to C.M. Martini any „, means that would assure expected fruits of priestly work" had ever been described ${ }^{2}$.

Priestly service doesn't mean performing a job in a professional meaning according to public opinion. It means a service, of which source is the Church. The priest appointed by the Christ, performs his duties as the servant of the Church, what means he cannot personally influence on the matter and nature of priestly activities. The spirit of service doesn't however lessen authority coming from priestly holy orders. Priests are favoured with great authority depending upon activity in favour of Christ. This authority if of a gift nature, which aim is the good, it may only be used as the service. ${ }^{3}$ However the potential of priestly service is being realized through different managers' functions in human size.

\section{Terminology of priestly mission' „professionalisation”}

Priests make selected social group, which members are of „professional" background to perform church's' service, as well as they perform spiritual profession. In term "profession” it means income, qualifications and job performing. Those elements are also present in priestly work. The basic tasks of priests are duties resulting from mission, which source is ancillary priesthood. Proper qualifications (knowledge, skills, qualifications) are achieved during seminar formation, and improve during permanent formation. While income in priestly service is closely related to the faithful's generosity, who take

\footnotetext{
1 J. Mariański, Religijność w procesie przemian, Warszawa 1991, pp. 332-333.

2 C.M. Martini, Davide, peccatore e credente, Casale Monferrato 1990, p. 29.

3 J. Galot, Postać kapłana w świetle Soboru Watykańskiego II, in: Kapłaństwo, Poznań-Warszawa 1988, p. 283..
} 
advantages from priest priestly service. Priestly work is of profession nature. This is why intellectual formation on the university level is needed, next priests are to obey church rules and highly rigorist ethical norms, so it is work based on exclusivity of priestly mission in Church, this is why priests make professionalized social group.

\section{2. „Professionalism” of priests}

The above term shouldn't surprise neither priests, nor incidental observers of priestly service. An appealing to the priests' vocation means that his works means performing precisely described activities at first. The priest fulfils his duties resulting from his canonic mission, yet at the same time he is submitted to all rigors of human actions. The priests authority of which sourcelis joining the power of holy orders together with the Church's mission cannot be separated from results of personal engagement in accepted duties' realization. The priest entirely acts and becomes the God's servant and the Church's representative this way and also mandatory of all seculars.

Professionalism is related to professional competence and expertness. Professionalism within priestly service means performing accepted duties and resulting tasks according to the Church's mission, while expertness points to proper preparations for performing priestly functions. Finally professional competences describe proper connection of theoretical knowledge and practical abilities, owing which all priests can fulfil their mission in the Church efficiently and carry the dialogue with the world.

\section{Priestly service}

Christ, the founder of the Church recruits his members in two ways: "Come and follow me" or "Go and preach the Gospel"4. The first vocation is of centripetal direction towards Christ - it is an invitation for following the Master and being with Him, to participate in Redemption. The second vocation is of centrifugal direction and its aim is to preach the Gospel and making the Redemption real in the Church, also

\footnotetext{
${ }^{4}$ See. H. Urs von Balthasar, Christlicher Stand, Einsiedeln 1977, pp. 111-115.
} 
developing the God's Kingdom in the world. The above two kinds of vocation join together in the priest's person and describe the nature of service, the presbyter fulfils within the Church and world- wide.

Piests' mission is primary indicated for common and the only mission of redemption ${ }^{5}$. That is priests vocation that individually unite each priest with Christ and Church. Different is however priests' activity in the world. There is a clear distance between mission fulfilled by priests and reality of the world. Due to this fact many presbyters, despite their priestly devotion and their intensive work over development of their spiritual life, undergo a crisis caused by conflict of roles, which fulfilment requires both; the Church and the world. Priestly mission is being realized on the edge of the Church and world. Priestly tasks require engagement in the Church's matters from hierarchs. While evangelistic activities, apostols and extensive (educational, cultural, behavioral, social) open the priests to the world, where the faithful realize their Christian vocation and make the God's kingdom. Seculars are devoted to making the Christ's Holy body through participation in all Church's actions not demanding the power of holy orders, keeping the hierarchy of their importance: presbyters ought to trustfully give tasks in the Church's service to the secular, „leaving them free in their actions, yes, properly encouraging them to work on their own"6.

Priests' mission may be divided into: priestly tasks (salutary mediation, performance of sacraments, modernization of active love, announcing the God's word) and management of community (heretic function - management, administrative works), evangelisational apostols' job in the Church and world-wide (constant proclamation of the Gospel and giving its proof) and also supplementary jobs. Priests due to being fortified with the rites of the Church perform functions of father and a teacher among God's people and for people (priestly mission), however all they are together with all faithful, the

${ }^{5}$ Cf. Jan Paweł II, Pastores dabo vobis, 74 (abbr. PDV).

6 Sobór Watykański II, Dekret o posłudze i życiu kapłanów Presbyterorum ordinis, 9 (abbr. PO). 
Lord's pupils and participants of his Kingdom.: „With all reborn in the water of christening the presbyters are brothers among brothers, as the members of the only and the same Christ's Body, of which building all should do"7.

\section{The main aim of priest's work - leading people towards Christ and the Church}

The basic task of priests is to announce Christ and His Gospel. R. Cantalamessa states that, evangelize means „start from beginning”. This beginning - is ,Jesus is the Lord". It is the first kerigmate, it's a proclamation, that what was written before the Gospel. Jesus had died for our sins, resuscitated for our resculpation. Jesus is the Lord. It is a grain all gospels came from. We have to sow this grain again. Jesus is the Lord"8.

Contemporary priests, also within traditionally religious societies, have to announce the fundamental (primary and the simplest) truth, of which the gospel is the source. Priests while undertaking the mission of evangelization, ought to admit the principle, that faith and high level of religious knowledge are not of a feet-back nature. According to Revelation announcing of the Gospel restores faith, and religious knowledge creates better or worse atmosphere for it acceptance. This is why evangelization is needed to both; religiously educated, and religiously illiterates, for the faith feeds itself with Christ's Word. And this word's feature is; simplicity, direction, accessibility, readability, honesty. The priest should however assume that as the evangelizator he is always dealing with a straight forwarded person who needs understandable proof of the word, not the theological treatments?

\footnotetext{
7 PO 9.
}

8 R. Cantalamessa, Wsłuchani w Ducha Świętego, Kraków 1994, p. 119.

9 „New times require (...), that Christian proclamation was transferred to contemporary human with new methods and expressed in readable language and forms, in order to the evangelic reply was understandable, reasonable and deep, and didn't deform or breach the essence of evangelic proclamation at the same time." Jan Pawel II, Przemówienie inauguracyjne wygłoszone na otwarcie obrad IV Konferencji Ogólnej Episkopatów Ameryki Łacińskiej Nowa ewangelizacja, postęp człowieka, kultura chrześcijańska, „L’Osservatore Romano” 13(1992)12, p. 24. 
The priests, both: as evangelizators, and priests may help to every man, yet they have to be close. Priest-evangelizators who will make borders, or give too difficult tasks, would never make a man to follow him. Jon Paul II says clearly; „the stimula towards new evangelization cannot be an attempt to «endear themselves» and to "fuss around» people (compare Ga 1,10), but responsibility for the gift, the God made in Christ, in whom we can get to know the entire truth about God and the man and gain a real life"10.

The basic principle of priest's mission of professionalization reveals in evangelization: the priest ought to be a man first of all, for a man directs his service to, needs a man, like the good needs the good, and love demands love. Such rule of priest's service „professionalism” assumes that the „outer” signs of priests' mission ought to be changed into the „inner” good for people, the priest services to. It is a task for both; priests and Christians.

The priest in order to become a professional, qualified, capable evangelizator has to have constant contact with seculars in the environment of their lives; It is the best school of humanity. I dare, to say here one of the pastoral's truth; the priest has to become "professional" through evangelization. Evangelisator is to start a contact with a man on the human level. Evangelization is a process of priests' mission professionalization, owing which what would be difficult to accept by the priest is possible to accept by an evangelizator. „professionalism" means thou searching for such solutions that will lead faithful towards Christ and teach them live in the church and love It. Avoiding evangelization ${ }^{11}$ is impossible.

The priest without human's face would have difficulties in performing pastoral mission of the Church. And who is a parish-priest, vicar who wrongly performs his duties? Priesthood and ministry don't automatically join together for, their „matter” is human-being and spirit. „professionalism” concerns then all human aspects of ministry

\footnotetext{
10 Ibid.

11 See. J. Przybyłowski, Duszpasterstwo parafialne w Archidiecezji Warszawskiej. Próba oceny pastoralnej, „Biuletyn Duszpasterski” 2(2009), pp. 52-67.
} 
mission and means constant improvement of human abilities, which make easier, even enable priests in some cases fulfilling their pastoral mission in the Church and world-wide.

Evangelization is to lead Christ's pupils towards Church. One my belong to the Church only with his heart, due to constant love. A man has for get to know the Christ first, take a Holy Gospel from Him and reply with love, before he becomes a member of the Church's community. Such process is called „church evangelization”. Priests-evangelizators should meet people in the world, be among them, in order to listen to Christ together and learn how to live evangelic love. It means ,avoidance of efforts" what means in priestly activity to fulfil Jesus's order, who doesn't say „wait till someone comes” but orders his apostols "go"12.

\section{Preparation of candidates to make their service "professional”}

Secular members of the Church formulate very specific demands regarding to the priest and his role in church's community ( positive sacrifice of life and service) or (negative not to involve in politics). The above and other postulates of seculars may be a creative aid towards future priests' preparation. Actually the time of isolation the seminaries, that didn't have a status of universities, and were treated only as some centers "professionally” preparing future priests has already finished. Nowadays majority of seminaries is within structures of theological faculties, that are being opened on universities not only catholic, but also secular ones.

Academic level of the priests preparation in size „doctrina” requires however considering more pastoral theology in making them „sanctities”, and also some knowledge from psychology, sociology and pedagogics in human formation ${ }^{13}$.

\footnotetext{
12 G. Miller, Tolerancja cnotą chrześcijańską. Znoście siebie nawzajem w miłości (Ef 4, 2), in: W służbie człowiekowi. Studium duszpastersko-katechetyczne, ed. Z. Marek, Kraków 1991, p. 138.

13 Cf. PO 12-21; PDV 58.
} 
"Professionalism” in priestly preparations doesn't however change the hierarchy in the meaning of priestly sanctity within their service, what had John Paul II emphasized" in a light of long experience and different situations, I became convinced that the real and efficient priesthood - cura animarum may arise from only from the priestly soil of sanctity”. Not material means, especially those „rich ones” are the secrets of priestly successes. Constant fruits of priestly difficult work are born on the base of priests' hearts. Of course the formation, studium, aggiornamento are needed; that is a proper preparation that enables priests to face all urgent priestly needs ${ }^{14}$.

M. Gogacz has precisely described the terms of the priests' „professional" preparation towards priestly service, who said that the basic postulate in future priests preparation is ", concern for philosophical and theological priests' education on the university level, as well as concern for their deep religious education. It is about such religious education, that would broaden the way of thinking, not only delivers erudition. And it is about such religious behavior, the would make the friendship with Christ a sense of life ${ }^{15}$. In such a formation of future priests, new possibilities open for pastoral theology, of which tasks is not only pointing to the Church's vision and fulfilment of its salutary mission in contemporary world, but also contribution in preparation and proper pastoral formation of future priests. The postulate of pastoral theology development is very timely. W. Goddijn writes that the conception of ,what shall we require from priesthood is needed in both; regarding formation of future priests and proper performance of priestly functions. Practical, pastoral theology is the weakest from theological sciences, not related to present humanistic knowledge with sociology and psychology"16.

14 Jan Paweł II, Dar i Tajemnica. W pięćdziesiątą rocznicę moich święceń kapłańskich, Kraków 1996, p. 87.

15 M. Gogacz, Warunki skuteczności apostolstwa świeckich, „Communio” 1(1986)6, p. 128.

16 W. Goddijn, Rola kapłana w Kościele i w społeczeństwie, in: Ludzie - wiara Kościót. Analizy socjologiczne, ed. B. Cywiński, Warszawa 1966, p. 205. 
Future priests' "professionalization"17 requires therefore some development of pastoral theology, what had John Paul II clearly named in apostols adhortation. Pastores dabo vobis. The priests formation ought to be carried out in such a way, that during shaping the pastoral sensitivity and preparation to responsibility for the whole pastoral mission realization - the human spiritual, intellectually and priestly formation - in very detailed understanding ${ }^{18}$ taught to be taken into consideration according to the Church's hitherto present experience and also to the new stimula coming from the pope's way of teaching. „Professionalization” of priestly service may clearly notice, that priestly function ought not to be,limited to charisma and fulfilment of accepted duties, resulting from priestly vocation. Even the most firmly fulfilled duties cannot justify neglectance of development in humanity size and also performed specialty. Priests cannot be demanded perfectionism from within human spheres of development, but it ought to be emphasized that their competences, professionalism ${ }^{19}$, knowledge and practical abilities require constant education. Abilities with mastery, natural abilities with educated skills unite within the priest, and first of all natural it's with charismatic enrichment of spirituality. Social status of the priests is described by his functions, but frankly saying it is conditioned by his personal culture, his knowledge, „professionalism and expertness", qualifications, but first of all spirituality based on good asceticism $^{20}$. In pastoral formation of priests a special attention ought

\footnotetext{
17 PDV 57.

18 Ibid., 58.

19 The term priesthood professionalization joins directly with the ministry. O. Schreuder says, „, The term priesthood professionalization includes elements that are beneficial for priesthood, like specialization and intensification of the proper religious function of the ministry, concentration of education and preparation to ministry, increasing their scientific level through introduction of academic studies and adaptation of teaching programme for pastoral needs" O. Schreuder, Zawodowy charakter kapłaństwa, in: Ludzie - wiara - Kościót. Analizy socjologiczne, op. cit., p. 240.

20 J. Bukowski, Filozofia spotkania, Kraków 1987, p. 274: „Priest, monk or hermit is someone for whom it's not enough to confess to God in everyday life, inner service, fulfilment of commandments, serving as an example. His love and need 'to go forward' is so strong that he wants to devote to it, closing himself to other
} 
to be paid to their preparation towards bible priesthood, that ought to be directed into; theology, hermeneutic and practical ${ }^{21}$.

\section{Basic condition towards „professionality” of priestly service}

Priesthood is the most important task in priestly service. It ought to be mentioned here the priest first serves to the church, hat has salutary and estachologic goal, and such a goal may be achieved only in the future world ${ }^{22}$. This salutary-estachological direction is of fundamental nature for priestly service. The priest acts in visible reality, but is aware at the same time, that he ought to deal with it in a perspective of invisible "God's Kingdom" that he makes real in a mystery way ${ }^{23}$. This basic principle of priestly services is known as per visibilia ansibilia - through visible to invisible reality ${ }^{24}$.

\section{Autonomy of priests' and secular faithful actions}

Autonomy of priestly actions may be better presented owing to "professionalism” of priestly mission. Priests fulfil different pastoral

opportunities of organizing his life. He desires to live for the God only, devoting him all earthy matters. He wants to do ascesy, understood and compromise-free engagement within self-work, even in wider meaning than commandments say. Ascesy is to assure a plentitude of life through getting to know its most difficult fields, and to live in truth, without any illusions and disappointments » So the ascesy is living the fullness of life. It is obvious, $\mathrm{f}$ we notice that he sees the fullness of life in absolute renouncement of earthy order and realization of spiritual christianism."

${ }^{21} \mathrm{~J}$. Kudasiewicz, Pismo św. w teologii i duszpasterstwie. Rys historyczno-metodologiczny, in: Biblia w nauczaniu chrześcijańskim, ed. J. Kudasiewicz, Lublin 1991, p. 38-40; According to Church's documents, the Bible ought to be 1) modern-introducing exegetic methods, 2) Theological getting to know with Revelation matter 3) ascetic - leading to everyday reading 4)priestly-practical - preparing to future work with Bible. See. J. Kudasiewicz, Formacja biblijna teologów i duszpasterzy w świetle Vaticanum II, „Kielecki Przegląd Diecezjalny”53(1977), p. 180.

22 Sobór Watykański II, Konstytucja duszpasterska o Kościele w świecie współczesnym Gaudium et spes, 40 (abbr. GS).

${ }^{23}$ Sobór Watykański II, Konstytucja dogmatyczna o Kościele Lumen gentium, 3 (abbr. LG).

24 Jan Paweł II, Katecheza Zadanie misyjne Kościoła w jego relacjach ze światem 21 VI 1995, 1. 
functions by realizing their mission. „Some in an ordinary parish priesthood, others in missions, some others in circles of tasks related to educating, tutoring and behaving youth, accompanying various circles and organizations, participating in tasks related to social life development, and also working with the suffering, sick and abandoned.

The ways are different, sometimes difficult to be described. There must be many of them and they must be different according to structure of human life, social processes, historical traditions and heritage of various cultures and civilizations"25.

Priests fulfil their pastoral tasks mostly within parishes. The main task of parishes body is salutary mission, fulfilled by ordinary priesthood, yet parishes community is the first place for evangelization and apostolic activities of the seculars; Council in decree Apostolicam actuositatem paid attention to it; The parish delivers a visible sample of community apostolate gathering all various properties in one and including them into the Church's commonness ${ }^{26}$. The above decree as well indicates that the seculars activities within parishes is necessary for the priests actions efficiency. Apostol's activities of the secular members of the parish ought to extend together with priests, in order to be recognized and direct form of participation in the Church's life ${ }^{27}$.

Participation of seculars in apostolate that is directly related to priesthood may disclose in preparation and performance of liturgy, in catechism teaching in priestly and social initiatives, in works of priestly councils ${ }^{28}$, owing which they give indirect aid in parish management. Priests don't feel lonely owing it, for they may count on

\footnotetext{
25 Jan Paweł II, List do kapłanów na Wielki Czwartek Kapłaństwo służebne (8 IV 1979), 6.

26 Sobór Watykański II, Dekret o apostolstwie świecki Apostolicam actuositatem, 10 (abbr. AA).

27 Por. AA 10.

28 Cf. Jan Paweł II. Adhortacja apostolska. Christifideles laici, 27.
} 
their competences and solidarity, understanding and also on generous help in many fields of parish's service ${ }^{29}$.

Autonomy of priestly actions of the priests in the Church is very closely related to the autonomy of secular faithful activities in the world. Vatican Council II says that the duty, but also the right of secular towards apostolate come from their uniting with Christ the Head. They are included to the Mystical Body of Christ through christianism and strengthened with the power of Holy Spirit through Confirmation, also called and assigned for apostolate. Secular faithful are included in royal priesthood and saint people (comp. 1 P 2,4-10) in order to bring spiritual offerings and announce Christ's Words. However though sacraments, particularly Eucharist, they are given love, that is somehow a soul of the entire apostolate ${ }^{30}$.

\section{Personal principles of priestly mission "professionalization”}

The problem of relations between God's and human's size of life and the Church's functioning ought to be solved before description of personal conditions of priestly mission fulfilment. God's people are commune first, of which aim is presentation and making redemption real. The Church is also human society, for it is made by Christ's pupils. This is why both: God's and humans are to be taken into consideration in pastoral activities. This is why priests, and most of all secular faithful who realize their Christian vocation in Church and the world, need not only Holy Gospel teaching and decree of

\footnotetext{
29 Jan Paweł II. Katecheza. Dziedziny apostolstwa świeckich: uczestnictwo w misji Kościoła 16 III 1994, 2. In all (secular) church's communes the activity is so much needed, that without it the apostology itself cannot be usually efficient (...) However the seculars (...) complement what their brothers lack in, they enliven both; priests spirit and the rest of the faithful (...) fed with active participation in liturgics life of their commune, they eagerly participate in their Apostol's works. They attempt those keeping far away, they eagerly co-operate in transformation of the God's Word, especially through catechization. They give their knowledge to the service of the Church, improve priestly work and also management of church properties" (AA10).

30 AA 3.
} 
faith, but also social principles of which subject would be the entire ecclesia commune ${ }^{31}$.

The basic principle personalizing pastoral activates s acceptation of vocation in Jesus Christ up to victory. „Such victory cannot exist without pains, even suffering, like Christ's Resurrection without a cross « And He already won today, even if he was lying of the ground, downtrodden, who loves and forgives - said Stefan Wyszynski, Cardinal - who like Christ gives his heart away, even life for brothers (24 VI 1966)"32.

The second principle of priestly activities personalization points to the value of human - being. This human ought to be affirmed just for himself, not for any other reasons! The human needs to be loved, because he is a human - the love needs to be required for him due to a special dignity he owes. The third set of words belongs to the essence of evangelic proclamation of the Christ and Church's mission ${ }^{33}$. The priest is called to develop his humanity by overcoming his weaknesses. Humanity is also a measure of priestly mission „professionalism”. This is why John Paul II clear order of placing the human in the center of Church's pastoral activity ought to be read: „A human is a way of the Church - the way that leads somehow at the base of all those ways, the Church ought to follow, because every human - with no exception - has been redeemed by Christ, because with the human with no exception - Christ is somehow united, even if human has no idea about it(...). Due to this man is a way of the Church, the way of its everyday life and experience, mission and pains - the Church of our epoch must be again and again aware of its «situation»-that is

\footnotetext{
31 „Many social problems may be solved with consideration of catholic social science, that is of integral part of Christian's proclamation, of it shows its real consequences for social life and makes every day work and fight for justice an element of Christ, the „Redeemer”. Jan Paweł II, Centesimus annus, 5.

32 Jan Paweł II, Homilia w czasie Mszy św. odprawionej na Stadionie Dziesięciolecia, in: Jan Paweł II, Pielgrzymki do Ojczyzny 1979-1983-1987-1991-1995-1997. Przemówienia, homilie, Kraków 1997, p. 237.

33 Jan Paweł II, Przemówienie w siedzibie UNESCO (2 VI 1980), in: Przemówienia i homilie Ojca świętego Jana Pawła II, Kraków 1997, p. 274.
} 
at the same time aware of its opportunities, that direct and disclose again this way. It must be at the same time aware of menaces, aware of everything, what seems to be humans life could become contrary this, that "more and more human»,That everything what is within it, could be proper to the real dignity of the human: simply he must be aware of everything, what is contrary ${ }^{34}$.

\section{To sum up}

An general conclusion comes to mind within summarization of conducted cogitation: the priest will never be only an employee in Christ's Church. Even if he accepts all tasks resulting from priestly mission (services towards Church's members), that are performed according to church's' regulations and demand proper qualifications (knowledge and expertness) gained during education and experience., of which source is pastoral practice, and even if it is work gratified with the faithful generosity, so the priest is always a servant, and his mission is a service. It doesn't exempt any priest from the duty of his actions professionalizing, using professional knowledge and gaining competences in church's' practice performing.

The priest while staying within the Church service is first of all the Christ's pupil, who is the only Master and Teacher. Such a relation between priest and the Christ makes, that as a priest he is appointed to the Church's members service, with whom he makes salutary commune, but at the same time he is appointed by diocese bishop, an administer of church society with delegated canonic authority. It means that NOT a commune „hires” him, he is only Christ's pupil sent by Him, however his identification is received from the Church, of which official representative is an ordinary of the place. He priest's mission in the Church understood this way requires absolute obedience to Christ on one hand, and on the other - an utter subordination towards Church. The priest doesn't' perform any job, he is not a hired employee, and doesn't completely satisfies conditions of professional job. Staying Christ's priest for eternity, in a church he is a servant appointed to serve the commune

\footnotetext{
34 Jan Paweł II, Redemptor hominis, 14.
} 
members. The priest belongs to The Church, makes the Church, serves to the Church and directs churches' society, has plentitude of rights as the Christ's priest and at the same time he is an executor of his ordinary orders. It may be said that the salutary power of priestly service with Church's authority delegated to the priest by the bishop of place are joined together within the priest. The priest is therefore a „salutary institution", this is why he fulfils his mission with the Christ's power, personally staying under authority of the Church.

Key words: Parishes, priest, autonomy of priests', priest's work, priestly service

\section{Biogram:}

Jan Kazimierz Przybyłowski - polski duchowny katolicki, teolog, profesor nauk teologiczych. Specjalizuje się w teologii pastoralnej. Pełnił funkcje prorektora ds. finansowych i naukowych Uniwersytetu Kardynała Stefana Wyszyńskiego w Warszawie oraz prodziekana ds. Naukowych na Wydziale Teologicznym tegoż uniwersytetu. Obecnie kierownik katedry Katedry Teologii Pastoralnej i Nauk Pomocniczych na Wydziale Teologicznym UKSW.

\section{Bibliography:}

Balthasar H. Urs von, Christlicher Stand, Einsiedeln 1977.

Bukowski J., Filozofia spotkania, Kraków 1987.

Cantalamessa R., Wstuchani w Ducha Świętego, Kraków 1994.

Galot J., Postać kapłana wświetle Soboru Watykańskiego II, in: Kapłaństwo, Poznań-Warszawa 1988.

Goddijn W., Rola kapłana w Kościele i w społeczeństwie, in: Ludzie - wiara - Kościół. Analizy socjologiczne, ed. B. Cywiński, Warszawa 1966.

Gogacz M., Warunki skuteczności apostolstwa świeckich, „Communio” 1(1986)6.

Jan Paweł II, Centesimus annus.

Jan Paweł II, Dar i Tajemnica. W pięćdziesiąta rocznicę moich święceń kapłańskich, Kraków 1996.

Jan Paweł II, Homilia w czasie Mszy św. odprawionej na Stadionie Dziesięciolecia, in: Jan Pawet II, Pielgrzymki do Ojczyzny 1979-1983-1987-19911995-1997. Przemówienia, homilie, Kraków 1997. 
Jan Paweł II, Katecheza Zadanie misyjne Kościoła w jego relacjach ze światem 21 VI 1995.

Jan Paweł II, List do kapłanów na Wielki Czwartek Kapłaństwo służebne (8 IV 1979).

Jan Paweł II, Pastores dabo vobis.

Jan Paweł II, Przemówienie inauguracyjne wygłoszone na otwarcie obrad IV Konferencji Ogólnej Episkopatów Ameryki Łacińskiej Nowa ewangelizacja, postęp człowieka, kultura chrześcijańska, „L’Osservatore Romano" 13(1992)12.

Jan Paweł II, Przemówienie w siedzibie UNESCO (2 VI 1980), in: Przemówienia i homilie Ojca świętego Jana Pawła II, Kraków 1997.

Jan Paweł II, Redemptor hominis.

Jan Paweł II. Adhortacja apostolska. Christifideles laici.

Jan Paweł II. Katecheza. Dziedziny apostolstwa świeckich: uczestnictwo w misji Kościoła 16 III 1994.

Kudasiewicz J., Formacja biblijna teologów i duszpasterzy w świetle Vaticanum II, „Kielecki Przegląd Diecezjalny”53(1977).

Kudasiewicz J., Pismo św. w teologii i duszpasterstwie. Rys historyczno-metodologiczny, in: Biblia w nauczaniu chrześcijańskim, ed. J. Kudasiewicz, Lublin 1991.

Mariański J., Religijność w procesie przemian, Warszawa 1991.

Martini C.M., Davide, peccatore e credente, Casale Monferrato 1990.

Miller G., Tolerancja cnotą chrześcijańską. Znoście siebie nawzajem w miłości (Ef 4, 2), in: W stużbie człowiekowi. Studium duszpastersko-katechetyczne, ed. Z. Marek, Kraków 1991.

Przybyłowski J., Duszpasterstwo parafialne w Archidiecezji Warszawskiej. Próba oceny pastoralnej, „Biuletyn Duszpasterski” 2(2009), pp. 52-67.

Sobór Watykański II, Dekret o apostolstwie świecki Apostolicam actuositatem.

Sobór Watykański II, Dekret o posłudze i życiu kapłanów Presbyterorum ordinis.

Sobór Watykański II, Konstytucja dogmatyczna o Kościele Lumen gentium. Sobór Watykański II, Konstytucja duszpasterska o Kościele w świecie współczesnym Gaudium et spes. 